\title{
What Are Elections For? Conferring the Median Mandate
}

\author{
Michael D. McDonald \\ Dept of Political Science \\ Binghamton University \\ P.O. Box 6000 \\ Binghamton, NY 13902 \\ UNITED STATES \\ Phone: 16077772946 \\ Fax: $\quad 16077772675$ \\ mdmcd@binghamton.edu
}

\author{
Silvia M. Mendes \\ Dept of Management \& \\ Public Administration \\ University of Minho \\ 4710 Braga \\ PORTUGAL \\ 351253605510 \\ 351253676375 \\ smendes@eeg.uminho.pt
}

\author{
Ian Budge \\ Dept of Government \\ University of Essex \\ Wivenhoe Park \\ Colchester CO4 3SQ \\ UNITED KINGDOM \\ 01206872499 \\ 01206873598 \\ budgi@essex.ac.uk
}

McDonald and Budge are grateful to the Netherlands Institute for Advanced Study (NIAS) for resident fellowships that gave rise to this work. Mendes is grateful to the University of Minho and the Fundação para a Ciência e Tecnologia for financial support while on leave at Binghamton University. 


\section{What Are Elections For? Conferring the Median Mandate}

Conventional mandate theory, sometimes termed majoritarian democracy, sees popular preferences being translated into public policy through voters choosing as their government the party whose policies a majority prefers. Crucially, this assumes that elections do decide which party forms the government. In fact this seldom happens.

If elections do not unambiguously designate governments, what do they do? One reaction, common to both classic representational theory and modern 'visions' of 'consociational' or 'consensus' democracy, is to limit their role to endorsing representatives. ${ }^{1}$ These then negotiate compromises on behalf of their constituents in a more considered way than election campaigning would allow. ${ }^{2}$ Acknowledging that there is a restricted role for elections and hence for voters in the democratic process is certainly one possible reaction to the failure of elections to designate governments unambiguously. It may even have an upside, in terms of the better policy solutions that can be reached through autonomous discussion and bargaining between parties. ${ }^{3}$ But it is not very democratic.

Our purpose here is to show that, even in PR systems with many parties, elections do confer a popular mandate that shapes legislative decision-making. This improves the democratic credentials of consensus democracy while respecting the elite bargaining processes that reportedly produce better policy. It also gets us away from incommensurable 'visions' of democracy, such as the majoritarian and consensus versions cited above. Instead, it replaces them with a unified standard by which democracy should and, as we show, broadly does operate.

\footnotetext{
${ }^{1}$ Edmund Burke, 'Address to the Electors of Bristol', quoted in Oskar Piest, ed, Reflections on the Revolution in France (New York: Liberal Arts Press, 1955), p. xv.

${ }^{2}$ Arend Lijphart, The Politics of Accommodation: Pluralism and Democracy in the Netherlands (Berkeley: University of California Press, 1968); Democracies: Patterns of majoritarian and Consensus Governments (New Haven: Yale University Press, 1984).

${ }^{3}$ Arend Lijphart, Patterns of Democracy: Government Forms and Performance in Thirty-Six Countries (New Haven: Yale University Press, 1999), pp. 243-301.
} 
This is achieved by shifting the focus of the mandate from government to the pivotal median party in parliament. ${ }^{4}$ If the parliamentary median is the choice of the median elector, the link is made between majority electoral preferences and what goes on in the legislature, where the median party has a controlling influence under the conditions specified below.

Spelling out the argument for the policy-determining role of elections in more detail, we start with the fact that under certain conditions their aggregate results reveal the policy preferences of the median voter. Given that the median is that policy position crucial to the formation of a popular majority, it gives every voter the most they can hope for under the existing distribution of preferences as revealed by equal voting. The proper role of an election can be seen as the identification of this socially optimal position. To be truly democratic, the rules for aggregating votes into seats should empower the voter median by ensuring that it is also the policy position of the parliamentary median.

For the same reasons that make the median elector crucial to forming a popular majority, the parliamentary median is crucial to building a legislative majority. Bringing the two into correspondence means that the policies a popular majority would endorse if it were asked about them directly are the ones favoured by the median party and hence close to those eventually approved by parliament. This implies that processes of elite bargaining in the legislature, even if insulated from direct electoral pressures, will still reflect popular preferences-as they must do, of course, to be really democratic. The median mandate provides a concrete mechanism through which convergence of the two medians can take place, rather than relying on elite goodwill.

Our extension of mandate theory from a government to a median mandate enables us to ask what the concrete embodiments of democracy have in common, rather than turning to the relativism of different 'visions' employing different evaluative criteria for what democracy should

\footnotetext{
${ }^{4}$ We use the terms 'median party in parliament' and 'parliamentary median' interchangeably. In both cases we are referring to the position of the party with which the median parliamentarian affiliates, along something like a left-right continuum. This concept is sometimes referred to as the 'weighted median party position' or the 'central party.' See Peter van Roozendahl 'Centre Parties and Coalition Formation: A Game-Theoretic Approach', European Journal of Political Science, 18 (1990), 325-48; 'The Effect of Dominant and Central Parties on Cabinet Composition and Duration', Legislative Studies Quarterly, 14 (1992), 5-36.
} 
be. That is, having a unified, mandate-based theory of democracy enables us to challenge assumptions of incommensurability. ${ }^{5}$ We can evaluate different institutional arrangements by applying a common norm: How well do they specify and empower the median electoral preferences? Seen in this light, proportional representation emerges as superior to its main rival, labelled variously as the single member district, Westminster, or majoritarian system.

\section{Conceptual Preliminaries}

Mandate theory, like many other approaches in political science, is both normative and descriptive. Its normative and descriptive aspects are closely linked. As a normative theory, it provides a justification for representative democracy as being uniquely sensitive to citizen interests. As a descriptive theory, it gives an account of how democracy works in fact. We could hardly justify democracy as institutionalising the mandate if we found that democracies in practice do not work that way. ${ }^{6}$

Reflecting these two aspects of the theory, our discussion here first of all spells out the conditions necessary for the alternative versions of a democratic mandate to operate and then proceeds to see how far they exist in actual democratic practice. The most important indicator of whether the conditions apply is how well working democracies produce the correspondences between voters expressed preferences and public policy that they are supposed to promote, a question we try to answer below with evidence from 20 democracies over the post-war period.

Before operationalising or even stating the two sets of conditions that stand behind the variations of mandate theories, we need to clarify one important question: what is the underlying conception of democracy implicit in our previous comments and in what ensues. Following recent

\footnotetext{
${ }^{5}$ As has been endorsed by G. Bingham Powell when he attributes to 'majoritarian' and 'consensus' democracy their own unique criteria for success, Elections as Instruments of Democracy: Majoritarian and Proportional Visions (New Haven: Yale University Press, 2000).

${ }^{6}$ As William Riker has written, political science research, "starts with a goal and searches for a way to attain it. ... The scientific question is "What institutions encourage the chosen morality?" Empirical analyses enter because "Description and analysis of causes (or more accurately, the analysis of occasions) are necessary for answering this question," Democracy in the United States (New York: Macmillan, 1965) pp. vi-vii.
} 
conceptual analyses, ${ }^{7}$ we see democracy's defining characteristic as its creation of "a necessary correspondence $\ldots$ between acts of governance and the equally weighted felt interests of citizens with respect to these acts."

The key element in the definition is the necessary correspondence. It is included in Saward's definition to answer a stock criticism: Would not a benevolent despot do as well for citizens' felt interests as a democracy? In terms of consensus democracy, the stock criticism could be translated into this query: Would not autonomous and benevolent representatives serve citizens' interests as well as or better than majoritarian democracy? The answer, in either form of the question, holds that a simple correspondence of interests and policy is not enough. What distinguishes democracy is its institutional mechanism for creating the correspondence. This mechanism is the democratic election. The centrality of elections to democracy stems from the fact that they provide a recurring opportunity for citizens to express and empower their interests.

If the link between election results and governance breaks down, for example through lack of a clear majority party to form a government, the correspondence between policy and preference is not created. To the extent this happens, democracy is attenuated. This is where the idea of a median correspondence comes in. Elections almost always identify a median electoral preference. Given its pivotal role in creating a majority, the median must be close to what the majority would endorse if it were asked directly. Having identified a median preference is no guarantee under representative democracy that it will become government policy, however, unless election rules ensure that the median party in the legislature is the one for which the median elector voted. To the extent the medians correspond, the system is more democratic. To the extent the rules make this correspondence capricious and arbitrary, the system is less than democratic. ${ }^{9}$

\footnotetext{
${ }^{7}$ Michael Saward, The Terms of Democracy (Cambridge: Polity, 1998); cf, Albert Weale, Democracy (London: Macmillan, 1999).

${ }^{8}$ Saward, The Terms of Democracy, p. 51.

${ }^{9}$ The 'power of the median' and its centrality to preferences have of course been put to use in many areas of rational choice theory. Duncan Black formulates the median voter theorem in his The Theory of Committees and Elections (Cambridge, Cambridge University Press, 1963), pp. 14-18; see Harold Hotelling 'Stability in Competition', Economic Journal 39 (1929), 41-57, and Anthony Downs An Economic Theory of Democracy (New York: Harper and Row, 1957). To our knowledge, however, ours is the first formulation to put forward explicitly a mandate theory based on its power and centrality to preferences, though other analysts, such as G Bingham Powell, have used median positions in the electorate as an
} 
Our normative criteria thus follow directly from the general standard for democracy spelled out above. In the next section we see how the different versions of mandate theory operationalise the creation of a 'necessary correspondence' between popular preferences and public policy, before going on to investigate how far the conditions of government and median mandates apply to contemporary practice.

\section{Extending Mandate Theory from Government to Median}

\section{Theoretical Conditions for a Government Mandate}

Government mandate theory can be characterized as saying that the policy preferences of a knowable and coherent majority of voters determine the winner of an election and that winner takes its turn at running government on the policy lines it had promised before the election. In its more detailed form, Table 1 summarises the theory as comprehensively as possible.

[Table 1 about here]

Conditions 1 through 6 are explicitly spelled out by the various authorities listed in the table notes, with somewhat different emphases depending on whether their focus is on the parties' role in offering choices or the voters' role in making them. Condition 1, party distinctiveness, says that for a mandate to operate parties have to offer a policy choice; otherwise there is no policybased reason to prefer one party above another. Conditions 2 and 3, voter information and motivation, say that voters must be informed enough to recognize party policy differences on offer and policy motivated enough to base their choices on the policy profile closest to their preferred position; otherwise their votes are not communicating policy information. With votes cast on the basis of policies, the voter majority condition, condition 4 , requires that a majority preference for a particular party be clearly registered; otherwise one cannot know what the majority prefers. Condition 5, electoral system translation, says that adherence to all the preceding conditions would go for naught if the electoral system mistranslates the voter majority. Finally, condition 6 , 
party policy commitment, says that the party in government translates its policy proclamations into policy; otherwise voters would elect whom they (thought that they) want but would not get what they want.

To check whether the conditions for a government mandate are actually met, we do not need to look into each and every one of the conditions. Each is necessary for a government mandate to operate. Thus failure with respect to any one condition indicates that a mandate is not present in the case in question. Given the conditions of the theory, it makes sense to concentrate on electoral majority endorsement of governments as it forms one essential mechanism postulated by the theory for creating a correspondence between popular preferences and public policy. However, it is not at all obvious that a majority mandate does emerge in contemporary democracies. Given the recognition, at least since Duverger, ${ }^{10}$ that electoral majorities are infrequent. A first test for a real government mandate being conferred asks whether knowable and coherent electoral majorities are actually evident in practice.

\section{Evidence for the Presence of a Government Mandate in Contemporary Democracies}

To the weight of Duverger's and other past evidence we can add our own results, from 20 democracies with 254 elections and 471 governments. Our data cover the first constitutionally authorized democratic election after 1949 through the formation of any government in 1995. Seats and votes through 1990 rely on data reported by Andrea Volkens and her colleagues, who themselves relied on compilations by Thomas Mackie and Richard Rose. ${ }^{11}$ After 1990, vote and seat data come from various annual political updates reported in the European Journal of Political

\footnotetext{
${ }^{10}$ Maurice Duverger, Political Parties: Their Organization and Activities in a Modern State (London: Metheun, 1959, reprinted 1964, translation by Barbara and Robert North).

${ }^{11}$ Andrea Volkens, Kai-Uwe Schnapp, and Jürgen Lass, Data Handbook on Election results and Seats in national Parliaments of 26 Contemproary Democracies, 1945-1990 (Berlin: WZB, 1992); Thomas Mackie and Richard Rose, International Almanac of Electoral History, $3^{\text {rd }}$ ed, (Washington: Congressional Quarterly, 1991).
} 
Research. Designations of governments, parties in government, and durations of governments come from the compilation by Jaap Waldendorp, Hans Keman, and Ian Budge. ${ }^{12}$

Table 2 categorizes election results in five single-member district (SMD) systems. Support among the electorate and the status of ensuing government(s) are combined into five possibilities.

1. An electoral majority produces a majority government.

2. An electoral plurality manufactures a majority government.

3. An electoral minority produces a majority government, where an electoral minority refers to a party receiving fewer votes than the plurality party.

4. An electoral plurality produces a minority government.

5. An electoral minority produces a minority government, where an electoral minority refers to a party receiving fewer votes than the plurality party.

[Table 2 about here]

Only 10.9 percent of the SMD elections have electoral majorities producing majority governments. Because these governments last slightly longer than other types, the majoritymajority status covers an average of 14 percent of the time in government. The modal outcome under SMD rules is for a single party to win an electoral plurality and have majority control of government. This occurred for 64.5 percent of the SMD elections and covers about 68 percent of government time. This is the modal result in all five SMD countries. In another 10.0 percent of SMD elections, most notably in Australia, we find an anomalous outcome where a party running second to the plurality party gains majority control of government. In 8.2 percent of the SMD elections, a plurality party did not receive enough of the usual bonus to win a seat majority but did win enough seats to form a minority government. Finally, on seven occasions a party with an electoral minority held the largest number of parliamentary seats, formed a government, but fell short of majority control.

\footnotetext{
${ }^{12}$ Jaap Woldendorp, Hans Keman, and Ian Budge, Party Government in 48 Democracies (1945-1998) (Amsterdam: Kluwer, 2000).
} 
It is clear from these results that a necessary condition for a government mandate, the emergence of an identifiable majority-supported party does not exist in these purportedly majoritarian, SMD-based, democracies. The plurality-supported governments that emerge do not meet the criteria for such a mandate, as there is no guarantee that they are not strongly opposed by the majority of electors who voted for other parties. Elections in these five democracies are thus often determining in the sense of deciding who wins but not majority-empowering, since no electoral majority exists for any single party or for a particular grouping of parties. The winning party can claim a mandate, but it is not known that it has been given a mandate.

How far do PR systems institutionalise the conditions for a government mandate? Table 3 shows, paradoxically, that they are far more likely than SMD systems to produce majority governments with groupings of parties that have garnered a majority of votes. This occurs in 53.7 percent of the governments forming under PR systems, which is five times more frequently than in SMD systems (see Table 2). Given the duration of these Governments, this condition amounts to majority-majority governance 55.4 percent of the time. However, only 10 of these cases are single-party majority Governments. ${ }^{13}$

On the face of it, this extensive majority-majority correspondence under PR rules meets the conditions for a government mandate. A fatal flaw exists however in the nature of the electoral majority manufactured in the process of putting together a majority coalition in the legislature. The electoral majority the government rests on is top-down, not bottom-up, and thus is not one created by the voters' expressed preferences.

While perfectly good as a theory in itself, and omnipresent as a justification for democracy the government mandate seems irrelevant to the practical workings of contemporary democracies. Its emphasis on empowering the majority is not met since a knowable and coherent electoral majority so seldom in fact creates a government. ${ }^{14}$

\footnotetext{
${ }^{13}$ The ten governments resulted from eight elections: Austria 1971 (one government), Austria 1975 (1), Austria 1979 (1), Germany 1957 (1), Ireland 1977 (2), Portugal 1987 (1), Portugal 1991 (1), and Sweden 1968 (2).

${ }^{14}$ It could be argued that the situation is better than this because electoral alliances of parties often provide two alternatives to the electorate, one of which gets a majority (e.g. left and right in France). It is only
} 
That does not imply that we ought to totally abandon the idea of a mandate from electorate to government. It is difficult to see any other mechanism whereby elections can translate popular preferences into policy under representative democracy. A temptation is to turn to direct democracy as the only way in which policy could be democratically determined. ${ }^{15}$ There is, however, the alternative already suggested. Alter the focus of the mandate from government to median party, and in so doing set up more realistic conditions for its conferment.

\section{Theoretical Conditions for a Median Mandate}

Suspend the idea that elections are about who governs and mass democratic governance looks very different. Instead of asking who governs, ask from what policy position does governance emanate? The answer is simple when parties give a broadly unidimensional form to the policy space and are motivated by the policy preferences that give rise to their alignment. The policy position in control is that of the party of the median parliamentarian. This is what Peter van Roozendahl has identified as the 'central' party. ${ }^{16}$

To see why consider Figure 1, where actors prefer any policy closer to their own preference on a left-right continuum. This puts $C$, at the median, in the most powerful position. Actors both to left and right need $C$ to form a majority. $C$ can thus bargain for a public policy close to its own position, by threatening to join the alternative majority if $C$ does not get its way. Compared to policy positions of its rivals on one wing, $C$ 's position will be preferred by partners on the other wing in whatever coalition it joins. Thus $C$ 's position will constitute the point towards which majority-backed policy always tends.

[Figure 1 about here]

It is important to recognise that this standard 'power of the median' argument applies both to electors and to policy motivated parties. ${ }^{17}$ It is the reason why the median position is so often

rarely, however, that these agree on a common programme before the election. As they generally do not electors still do not know what policy package they are voting for, so the conditions for a government mandate are still not being met.

${ }^{15}$ Ian Budge, The New Challenge of Direct Democracy (London: Polity, 1996).

${ }^{16}$ van Roozendahl 'Centre parties and Coalition Formation'; 'The effect of Dominant and Central Parties'.

${ }^{17}$ Black, The Theory of Committees and Elections. 
used as an indicator of majority preferences. ${ }^{18}$ Without the median voter, a knowable and coherent majority simply cannot be formed, by definition. Because the median position is so crucial, actors located there can bargain, implicitly or explicitly, to have the majority-supported position close to their own. Their trump is the credible threat to form an alternative majority with the people on the other wing. Thus majority preferences (under the conditions specified) must be at or near the median position.

The same logic must apply to parties if their internal discipline is tight enough for them to be regarded as unitary actors. Even if $\mathrm{C}$ is very small compared to the other parties these still need C's support to form a majority. Just as in the electorate, party $C$ can bring the final policy close by threatening defection to an opposing wing. Under majority voting rules in a legislature, $\mathrm{C}$ is the policy king.

We spell out the details of the necessary conditions for a median mandate in Table 4. They closely resemble those for the government mandate in Table 1. This is not surprising as the electoral majority on which a government mandate rests is a special case of the median mandate; where there is a single-party majority, the median position is by definition part of it. The reverse does not hold however; there can be a median position without the majority voting for a single party.

[Table 4 about here]

Under any mandate theory, parties have to present a choice to electors; otherwise there is no policy-based reason for voters to prefer one party over another. Thus once again we have Condition 1, party distinctiveness. Conditions 2 and 3, voter information and motivation, like conditions 2 and 3 for the government mandate, say that voters must be informed enough to recognize party policy differences on offer and policy motivated enough to base their choices on the policy profile closest to their preferred position; otherwise their votes are not communicating

\footnotetext{
18 . John D. Huber and G. Bingham Powell, 'Congruence between Citizen and Policymakers in Two Visions of Liberal Democracy', World Politics, 46 (1994 ), 291-326; Powell, Elections as Instruments of Democracy, pp. 163-67; ; G. Bingham Powell and Georg Vanberg, 'Election Laws, Disproportionality and Median Correspondence: Implications for Two Visions of Democracy', British Journal of Political Science, 30 (2000), 383-411.
} 
policy information. Condition 4, a shared policy space, requires that voters and parties communicate in largely the same political language, probably a left-right dimension; otherwise what the voters think they have expressed and what the parties think that they have heard will not connect the two. Condition 5, electoral system translation, says that the election outcome, in terms of the distribution of seats among parties in parliament, makes the party of the median parliamentarian the same as the party preferred by the median voter. Condition 6 , party policy commitment, says that there must exist a self-motivation among parliamentarians to see their policy preferences converted into actual policy; otherwise they would not empower the parliamentary median for policy purposes. A robust comparative finding on coalition governments is that over 80 percent incorporate the legislative median party. ${ }^{19}$ Where they do not, this is often under minority governments where the median can exercise control over legislative coalitions anyway. ${ }^{20}$ Finally, Condition 7 summarises standard power of the median reasoning previously discussed, so does not require a detailed justification here. We can refer again to Figure 1 which demonstrates that, logically, actors with preferences located along such a continuum who prefer nearer policy outcomes to ones further away will ally with the median actor, who can therefore swing the policy in its direction by the threat of changing allegiance to the other wing.

It perhaps bears repeating that the power of the median result applies both to electors and legislative parties. However it has a somewhat different standing at the two levels. In the case of electors it justifies using the median position to estimate what the majority preference is, as we show immediately below.

\section{Talking to Each Other in Policy Space}

Under median mandate conditions a shared policy space becomes crucial for recognizing that a mandate has been assigned. It is what allows us to identify a median without requiring a country's

\footnotetext{
${ }^{19}$ van Roozendahl 'Centre Parties and Coalition Formation ; 'The Effect of Dominant and Central Parties. See also: Ian Budge and Michael Laver, 'The Relationship Between Party and Coalition Policy in Europe: An Empirical Synthesis', in M. J. Laver and Ian Budge, eds, Party Policy and Government Coalitions (London: Macmillan, 1992), p. 415-20; Wolfgang C. Müller and Kaare Strøm, 'Conclusion: Coalition Governance in Western Europe', in Wolfgang C. Müller and Kaare Strøm, eds, Coalition Governments in Western Europe (Oxford: Oxford University Press, 2000), pp. 563-69.
} 
political space to be unidimensional in some fundamental and absolute sense, and by relaxing the assumption renders the conditions for such a mandate widely applicable. But we must ask, are we not running into problems of cyclical voting and policy incoherence ${ }^{21}$ by not imposing unidimensionality as necessary condition?

To fully evaluate the condition of a shared policy space, we need to start with the basic structure of the policy space and move on to link it to shared communication in general and medians in particular. An important starting point is to note that the dimensionality of policy space depends less on the number of issues or polices involved than on the number of parties. While the policy space over $k$ issues approaches something on the order of being $k$-dimensional, parties structure the $k$-dimensional space into much smaller order of dimensionality by virtue of their limited numbers. That makes the conversation between voters and potential governors highly structured, where the structure comes principally from the parties on offer at election time. At the lower extreme of a two-party system, unidimensionality is true by definition. Three parties might require two dimensions, four parties three dimensions, and so on; so that the hypothetically conceivable upper bound of the dimensionality of the policy space of an election as structured by $P$ parties is $P-1$. At this upper extreme, with a space of $P-1$, each party is an entity unto itself, offering a programme incommensurable with the programme of every other party. This might be a description of a system organized by exclusively single-issue parties. One party takes a position on abortion and nothing else, another party takes a position on agricultural subsidies and nothing else, another takes up wetland preservation and nothing else, and so on. However, this is not a party system known to anyone. Rather, most parties take positions on a range of issues, and most observers, experts and citizens in the mass public alike, can characterize them along something like a single left-right dimension. ${ }^{22}$

\footnotetext{
${ }^{20}$ Kaare Strøm, Minority Government and Majority Rule (New York: Cambridge University Press, 1990).

${ }^{21}$ Kenneth J. Arrow, Social Choice and Individual Values, $2^{\text {nd }}$ ed, (New Haven: Yale University Press, 1963).

${ }^{22}$ Surveys of experts asked to rank their national parties along a left-right scale are burgeoning. Most respondents find no difficulty in using a left-right characterization; nor do electors when asked to do the same in national voting studies. See Francis Castles and Peter Mair, 'Left-right Political Scales: Some 'Expert' Judgements', European Journal of Political Science, 12 (1984), 73-88; John D. Huber and Ronald
} 
From this structured policy space of elections, the position of a median voter will emerge from the aggregate vote results and will be generally knowable provided that a unidimensionality of party alignment holds only roughly, only very roughly as it turns out. A sometimes overlooked contribution to the discussion of dimensionality and majority cycles is Richard Niemi's demonstration that there is only a small likelihood that the policy profiles of members of a collectivity, even randomly generated profiles, over $N$ persons considering $P$ parties would configure so as to cycle. ${ }^{23}$ Political parties campaigning in elections provide one of the hugely important instances of a structure-induced equilibrium that exists in democratic politics. ${ }^{24}$ If only two parties are on offer, a definite equilibrium has been induced. What Niemi's demonstration tells us, however, is that beyond two-party systems a number of parties within reasonable limits is likely to induce an equilibrium position. And, while this holds even at the extreme of randomly generated voter profiles, voters' policy profiles are not generated randomly. Numerous institutional devices, including the parties themselves and the media, help to induce a dimensionalizing structure on political discussion and debate. Such an attitudinal structure makes it even less likely (i.e., less likely than a small chance) that electoral majorities will cycle. There

Inglehart, 'Expert Interpretations of Party Space and Party Locations in 42 Democracies', Party Politics, 1 (1995), 73-111. Ronald Inglehart and Hans-Dieter Klingemann 'Party Identification, Ideological Preference and Left-Right Dimension among Western Mass Publics', in Ian Budge, Ivor Crewe and Dennis Farlie, eds, Party Identification and Beyond (London and New York: Wiley, 1976), pp. 243-73. In Matthew Gabel and John D. Huber, 'Putting Parties in Their Place: Inferring Party Left-right Ideological Positions from Party Manifesto Data', American Journal of Political Science, 44 (2000), 94-103, an extensive analysis of party programmes over 15 post-war democracies found a left-right dimension emerging as the principal and only shared dimension; see also, Ian Budge, Hans-Dieter Klingemann, Andrea Volkens, Judith Bara, Eric Tannebaum, et al., Mapping Policy Preferences: Estimates for Parties, Electors, and Governments 19451998 (Oxford, Oxford University Press, 2001), pp. 1-49. Analyses of electoral data stretching over 100 years similarly identified a left-right dimension as the one on which to base analysis, Stefano Bartolini and Peter Mair, Identity, Competition and Electoral Availability: The Stabilisation of European Electorates 1885-1985 (Cambridge: Cambridge University Press, 1990).

${ }^{23}$ Richard G. Niemi, "Majority Decision-Making with Partial Dimensionality', American Political Science Review 63 (1969), 488-97; 'Why So Much Stability: Another Opinion', Public Choice, 41 (1983), 261-70.

${ }^{24}$ Kenneth A. Shepsle, 'Institutional Arrangements and Equilibrium in Multidimensional Voting Models', American Journal of Political Science, 23 (1979), 27-59; Kenneth A. Shepsle and Barry Weingast, "Structure Induced Equilibrium and Legislative Choice', Public Choice, 37 (1981), 503-19. In essence, it is the parties that usually resolve the potential for Arrovian incoherence in mass elections. They impose a structure on the elections that is, for any one election, in violation of Arrow's condition that there be no restriction on the way policy bundles are put together. That is, while there is no restriction in the long run, in that parties with any type of policy profile can enter the electoral competition, for any one election the bundles are restricted to what the parties in that elections are offering. Thus, when the number of parties, $P$, is less than the number of permutations of the ways policies could be put together into bundles, an Arrow condition is violated and the impossibility of purging incoherence is largely abated. 
surely are policy profiles among electors, which when conjoined with a distribution of voter percentages, will produce majority cycles. ${ }^{25}$ However, it would be the height of incautious cautiousness to elevate the possibility that there may not be a median voter to something like a certainty that there will not be a median voter.

These considerations help explain our relaxed tone on unidimensionality. In practice, however, the basic ordering of preferences is likely to be characterized reasonably well as spread along the well known left-right continuum. Apart from expert and party use of it as a preferred frame of reference (see n. 22) the most telling evidence comes from the review of mass survey research on collective representation carried through by Philip Converse and Roy Pierce ${ }^{26}$ and more recently by Pierce, Warren Miller, and their collaborators. ${ }^{27}$ Their analyses show that voters do have a strong sense of where they themselves and the parties stand on the broad contours of policy as indicated by the left-right dimension. Pierce summarizes the findings by saying:

The issue to which they [voters] are likely to give high priority $\ldots$ is the ideological super-issue' ...: the left-right dimension on the European continent or the liberal-conservative dimension in the United States. Voter-party congruence on more specific issues, even those that are traditionally linked to the ideological dimension, is much more limited. ${ }^{28}$

\footnotetext{
${ }^{25}$ We can give an example using three alternatives, with Britain in mind. With three alternatives, there are six possible policy profiles: $\mathrm{ABC}$; $\mathrm{ACB} ; \mathrm{BAC} ; \mathrm{BCA}$ : $\mathrm{CAB}$; $\mathrm{CBA}$. Imagine among 120 voters the vote splits exactly equally across the six profiles-20,20,20,20,20,\& 20. This will create a cycle. Change any one person's preference, however, say from profile \#6 to \#1, and there is no cycle. Worse for the proposition that there is some high probability of a cycle, the six profiles are probably not anything near to equally likely. For example, there are probably not too many Britons who have preference orders of (Con, Lab, Lib) or (Lab, Con, Lib); rather, most Britons probably have profiles of (Con, Lib, Lab), (Lab, Lib, Con), (Lib, Con, Lab), (Lib, Lab, Con); see A. Colman and I. Pountney, 'Borda's Voting Paradox: Theoretical Likelihood and Electoral Occurrences', Behavioral Science 23 (1978), 15-20. Niemi's point is that it would take an unlikely distribution across the four common profiles and the two uncommon ones to produce a cycle. In short, having multiple dimensions does not imply that there will not be a median voter; rather, multiple dimensions mean that you cannot guarantee with certainty that there will always be a median voter. ${ }^{26}$ Philip Converse and Roy Pierce, Political Representation in France (Cambridge, MA: Harvard University Press, 1986).

${ }^{27}$ Warren Miller, Roy Pierce, Jacques Thomassen, Richard Herrera, Sören Holmberg, Peter Esaiasson, and Bernhard Wessels, Policy Representation In Western Democracies (Oxford: Oxford University Press, 1999).

${ }^{28}$ Roy Pierce, 'Mass-Elite Issue Linkages and the Responsible Party Model of representation', in Miller et al., Policy Representation in Western Democracies, p. 30.
} 
By simply casting a vote for the nearest party on this dimension, communicated to them by parties and the media, a voter can register her or his preference for a policy programme on shared criteria. The overall distribution of percentages based on everyone voting for their preferred party then designates the median voter position and the party closest to it. ${ }^{29}$

\section{The Median Mandate: Does It Actually Operate?}

The median mandate rests on a more subtle and extended argument than the government mandate. Nevertheless, a first check on whether its conditions apply in practice can be made by investigating the correspondence between electoral and government policy preferences. If the correspondence exists, it does not prove the institutionalization of the correspondence so vital to the idea of the mandate. However, we can then look at further evidence, such as variation in the extent of correspondence between different electoral systems, PR being expected to match up to the conditions better given its explicit purpose of matching the voter strength of parties with seat strength in parliament. The absence of any actual correspondence would, on the other hand, negate the idea of necessary correspondence entirely and conclusively demonstrate the absence of conditions for a median mandate.

\section{Data}

Our data cover the same 254 elections giving rise to 471 governments in the 20 countries that we used to look into the government mandate thesis. To investigate median correspondence, the most obvious approach, given the discussion above, is to identify the positions of parties and voters along a left-right dimension. To do this we start with left-right party scoring from the

\footnotetext{
${ }^{29}$ This makes voting a simple act; one votes a sincere preference. Parties, motivated as they are assumed to be by their own policy preferences, will see to it that the position of the median party controls policy. This reasoning supplies a straightforward explanation for sincere voting, compared to, for example, the Downsian conjecture that voters in multi-party PR systems are driven to treat voting as an expressive act because their rational abilities have been overwhelmed, An Economic Theory of Democracy, pp. 142-63. Indeed, ironically, rational voting calculations are likely to be more taxing in SMD systems than PR systems. In an SMD system with more than two parties, there is a strong likelihood that the electoral system will manufacture a majority (median) party in parliament. That would provide an incentive for some voters to take into account how the electoral system translation might affect the designation of the median (majority) party in parliament.
} 
Comparative Manifesto Project (CMP), using the CMP98 release. ${ }^{30}$ We apply the operational strategies described below, but first provide the overview provided in Table 5. The left portion of the table reports the number of governments, government sequence numbers, the caretaker and non-partisan governments, and the number of elections. ${ }^{31}$ The right portion reports the average left-right position of the median voter throughout the time periods, left-right positioning of the parliamentary median, and the weighted mean position of governments, where the weights correspond to the relative number of parliamentary seats among parties in government.

[Table 5 about here]

Party Left-Right Positions. As noted, the positions of parties along the left-right dimension are taken from CMP98, with adjustments noted below in the cases of Iceland and Portugal. The CMP has coded the statements of party election programs into 56 policy categories; of these, 13 categories are taken as indicators of policy positions emphasised by the "left" and another 13 are taken as indicators of policy positions emphasised by the "right". The left-right measure is constructed for each party in each election by subtracting the sum of its left statements from the sum of its right statements. ${ }^{32}$ Our preliminary observations of the left-right positions of Icelandic and Portuguese parties revealed that parties in these two countries were making large jumps to the right in one election only to move just as far to the left in the next election. More detailed analyses revealed that nearly all of these movements were the result of Icelandic and Portuguese parties sometimes placing a great deal of emphasis on their claim to holding legitimate political authority, one of the 13 CMP categories indicative of being on the political right. ${ }^{33}$ We concluded that claims to political authority in these two countries are not to be taken as an indicator of a rightleaning political emphasis. Therefore, the left-right scores of Icelandic and Portuguese parties are

\footnotetext{
${ }^{30}$ Budge et al., Mapping Policy Preferences .

${ }^{31}$ Woldendorp et al., Party Governments, is the source for government identifications, government sequence numbers, and the caretaker and nonpartisan status.

32 Budge et al, Mapping Policy Preferences 2001, 21-24.

${ }^{33}$ The political authority category involves favorable mentions of strong government, including government stability and statements about a party's competence to govern, Budge et al. Mapping Policy Preferences $p$. 224.
} 
calculated using 25 policy categories, excluding political authority, from the sum of the "right" emphases.

The left-right placements of parties by the CMP have been shown to be a reliable and valid measure when evaluated against expert and mass perceptions of party Left-Right positions. ${ }^{34}$ An especially important benefit of the CMP data is that they record changes in party positions from one election to the next. Expert and mass survey data on party positions, on the other hand, have been collected on only a few occasions. Moreover, it appears that expert perceptions of party position across a decade, comparing the Castles-Mair data with the Huber-Inglehart data, ${ }^{35}$ are so stable as to eliminate any possibility of taking account of party movements. ${ }^{36}$

Median Voter. The position of the median voter is calculated as a variation on the measurement strategy devised by HeeMin Kim and Richard Fording using the CMP data (see the Appendix below for the details of this technique). ${ }^{37}$ We have made two adjustments to their original operationalisation. First, we modified the Left-Right positions of Icelandic and Portuguese parties as described above. Second, when the farthest left or farthest right party in a system is involved in the formula, we require that the voter distribution around that party take a form that we find more plausible than that implied by the Kim and Fording calculation (see the Appendix). The measure produces eminently reasonable country placements, column 4 of Table 5, which show, for example, Australia, consistent with its post-war political history, as the most right-leaning country, Germany as centrist, and Norway most to the left.

Parliamentary Median. We identify a parliamentary median by the position of the weighted median party. That is, a parliamentary median is at the left-right position of the party with which the middle parliamentarian affiliates, given the left-right alignment of parties according to their

\footnotetext{
${ }^{34}$ Gabel and Huber, 'Putting Parties in Their Place'; Michael D. McDonald and Silvia M. Mendes 'The Policy Space of Party Manifestos', in Michael Laver, ed, The Policy Space of Political Actors, (London: Routledge, 2001).; Checking the Party Policy Estimates: Convergent Validity', in Budge et al., Mapping Policy Preferences, pp. 127-41.

${ }^{35}$ Castles and Mair, Left-Right Political Scales; Huber and Inglehart, 'Expert Interpretations of Party Space and Party Locations'.

${ }^{36}$ McDonald and Mendes, 'The Policy Space of Party Manifestos, p. 100.

${ }^{37}$ HeeMin Kim \& Richard Fording, 'Voter Ideology in Western Democracies, 1946-1989', European Journal of Political Science, 33 (1998), 73-97; 'Extending Party Estimates to Governments and Electors', in Budge et al., Mapping Policy Preferences, pp. 157-77.
} 
CMP scores. The results of ten elections placed the member between two parties. In these cases we have scored the median as the midpoint between those parties.

Government Policy Position. We calculate the left-right position of a government as the weighted mean position of the parties in government, where the weights are the parliamentary seat percentages among parties in government. ${ }^{38}$ Using parliamentary seats as the weights is justified by repeated findings that government ministries are usually allocated to government parties in proportion to the seats they hold in parliament among the parties in government. ${ }^{39}$ Using a weighted average to indicate a government's left-right position is based on the assumption that parties in government influence policy in proportion to the cabinet posts they occupy. When there is just one party in government, that party's left-right position is the government's position; the party holds 100 percent of the weight of the parties in government. When there are two parties in government one with 75 seats and the other with 25 seats, then the position of the party with 75 seats has three times as much weight in the calculation of the government's position compared to the party with 25 seats.

In order to provide a modest reliability and validity check, we have compared our government policy scores with others calculated in the same way but using expert scores. For 32 Governments of the early 1980s and early 1990s for which we have parallel scores, $r=.82 .{ }^{40}$

\section{Findings}

The first check on whether the conditions for a median mandate exists is to examine the end results of the political process and ask how well the policy positions of governments line up with the expressed policy positions of their electorate. Finding persistent policy correspondences does not, to be sure, demonstrate a necessary correspondence as required by the median mandate, but it is certainly evidence in its favour. Institutional mechanisms for achieving correspondence come in

\footnotetext{
${ }^{38}$ Powell, Elections as Instruments of Democracy pp. 173-74. Huber and Powell, 'Congruence between Citizen and Policymakers in Two Visions of Liberal Democracy'.

${ }^{39}$ Eric Browne and Mark Franklin, 'Aspects of Coalition Payoffs in European Parliamentary Government', American Political Science Review, 67 (1972). 453-69.

${ }^{40}$ Scores using expert survey scores are taken from Powell, Elections as Instruments of Democracy, pp. 1801 and $184-5$
} 
when we compare policy correspondence under PR and SMD. PR is designed to reflect vote proportions in the distribution of parliamentary seats and thus bring the electoral and parliamentary medians into alignment. Policy correspondence ought to be greater where these conditions for a median mandate are better effected, i.e., under PR.

Table 6 shows nation-by-nation incongruence, long-term representativeness (higher scores actually indicate less representativeness), and responsiveness. Our measure of incongruence is calculated as the absolute value of the difference between the weighted government left-right position and the left-right position of the median voter at the election preceding the government. Incongruence addresses an important element in an analysis of electorate-government correspondence, but it is only part of what is at issue. Among other things, it stacks the deck against a finding of correspondence in SMD systems compared to PR systems. One of the main arguments often advanced in favour of SMD is its ability to produce clear-cut alternation between governments. Governments of both left and right may be incongruent with electors' preferences at the time of any one election. However, over a series of alternating governments the policy incongruities may cancel each other out, leaving the mean over-time policy position of government close to that of the electorate. Therefore, to the analysis of congruence we add an analysis of representativeness, measured as the average difference between the position of the median voter and government left-right position. By going beyond the absolute value calculation of incongruence, this analysis treats representation as more than a one-off phenomenon in one single election, independent of what happens at other elections. It is not that this is important and the congruence is not. Both are important, so we present analyses of both.

[Table 6 about here]

The left most column reports our incongruence results. The five SMD nations show relatively high incongruence. The incongruence scores across SMD systems average nearly 15 and exceed 12 in four out of five nations, Canada being the exception. In contrast, the average incongruence across PR systems is 7.6 and exceeds 10 in only three of the 15 countries. 
Two conclusions follow from these results. The first is that in the majority of the democracies we examine there is a respectable level of congruence between electors' expressed preferences and government policy positions. In 13 out of 20 democracies the gap between the two is less than 10, which substantively is about the difference between a party of the Liberal party family and a party of the Conservative party family. ${ }^{41}$ However, 12 of these 13 have PR elections, leading to a second conclusion, that PR produces more congruence than SMD (7.6 compared to 14.8 , on average).

Both results are expected and offer some support to the argument that conditions for the median mandate are present in post-war democracies. ${ }^{42}$ In particular, the contrast between election systems makes this point PR is explicitly designed to reflect electoral preferences for parties more clearly in the results, by matching up vote and seat shares, and thus linking the median voter to the median party. If policy congruence were not improved under these circumstances, we would begin to doubt whether the median mandate actually worked in practice. But, as we have said, congruence is only a part of what is at issue.

In the second column of Table 6 , we report the average unrepresentativeness for each of the 20 nations, along with summaries by electoral system type. With these results, the case for the median mandate comes more clearly into focus. The average representational bias under SMD systems shows that incongruities in single elections are compensated over time, with an average of only 5.6, in contrast to an average incongruence of 14.8. This is an across time compensation for incongruence that amounts to a 9.2 unit reduction, which means proportionately that government alternation reduces incongruence by $62 \%(1-[14.8-5.6]=.62)$. It is not as if across-time compensation operates just in SMD systems. The average representational bias among PR systems is only 1.5. That is a 6.1 unit reduction, which proportionately equates to alternations reducing incongruence in PR systems by 82 percent $(1-[1.4 / 7.6]=.82)$.

\footnotetext{
${ }^{41}$ To provide an idea of the metric of the CMP scoring in substantive political terms we report average party scores by party family: Communist $=-32.2 ;$ Greens $=18.4$ Social Democrats $=-18.3$; Agrarians $=0.1$; Liberals $=1.2 ;$ Christians $=1.6$; Conservatives $=10.0$.
} 
These conclusions would go for nil, or very nearly so as far as the median mandate thesis is concerned, if the close average correspondences were not much tied to elections. One might imagine that a good deal of the congruence is a matter of parties and voters in the same country sharing a somewhat similar policy space, even if the two are not coordinated with one another by elections. ${ }^{43}$ This would mean that the correspondence is present but, contrary to Saward's requirement, that elections would not be creating the correspondence. Analyses of responsiveness tell us about this possibility explicitly, for responsiveness is the degree to which movement in the median elector position is matched by similar movement in the government policy position. ${ }^{44}$ Therefore, the evidence consistent with the median mandate is much strengthened by our findings on responsiveness, appearing on the right-hand side of Table 6. Coefficients for this relationship are significant in all but the two SMD countries of France and New Zealand. The correlations however are pretty consistently higher under PR than SMD, while standard errors of estimate are generally lower under PR, indicating that relationships fit better to the individual data-points there. In substantively important terms, this tells us that responsiveness exists as a general tendency in both types of electoral systems but the tendency is more reliable under PR.

The responsiveness findings are surprising inasmuch as one of the long-standing criticisms of PR is that it lacks dynamism. This was a stridently expressed criticism of PR levelled by

\footnotetext{
${ }^{42}$ On these two points, similar findings are reported by Powell's in Elections as Instruments of Democracy; see also: Huber and Powell, 'Congruence between Citizens and Governments; G. Bingham Powell and Georg Vanberg, 'Election Laws, Disproportionality and Median Correspondence'. But see n. 41, below. ${ }^{43}$ Alternatively, one might also imagine that congruence is an artifact of a measure of survey-based measures of citizen ideological positions. For example, as we describe in the Appendix below, survey-based measures of citizen left-right positions appear to contain little valid cross-national variation. According to survey-based evidence, median voters in Norway, Sweden, Australia, the United States, among others, appear to be located at or very near to the center of the survey scale, as if respondents are norming their selfplacements in left-right space to the center in their own country regardless of how their national left-right space compares to that in other countries. This lack of meaningful cross-national variation in survey-based median voter measurements leaves one wondering whether, for example, Powell's findings in Elections as Instruments of Democracy (see also, Huber and Powell, 'Congruence between Citizens and Governments'; Powell and Vanberg, 'Election Laws, Disproportionality and Median Correspondence') are principally a matter of governments in PR systems tending toward the middle without there being any electoral coordination.

${ }^{44}$ We conducted the same analyses using two alternative methods of scoring party positions, which in turn affects the scoring of median voter and government positions. First, we scored all parties as having a leftright position equal to its mean value over the entire post-war period. Second, we scored their positions with a three-election moving average, a sort of compromise between allowing party positions to change with each election and assuming, implicitly via the mean scoring, that party positions are constant. The results are
} 
Hermans in the interwar period, and by others since. ${ }^{45}$ Table 6 shows little evidence of this. On the contrary, the rules designed to mirror election results in parliamentary composition seem to make government more consistently responsive to electoral preferences.

Considered overall, therefore, both types of election systems appear to be operating in ways that are generally consistent with the median mandate thesis. Of the two, however, PR systems are generally more congruent, less biased, and more reliably responsive than SMD systems. Why is this? The most plausible explanation adds weight to the hypothesis of a median mandate at work.

SMD systems come up short on the two critical features of sparse party offerings and higher distortions of vote-to-seat translations. We know from a long train of evidence that SMD systems generally, and almost uniformly, have fewer parties than PR systems. ${ }^{46}$ Given our assumption of policy motivation, meaning among other things that parties stick with their characteristic policy position, we would not expect parties to converge to the centre (and on our data they do not). In total, then, SMD systems encourage a relatively small number of offerings, none of which are generally close to the median voter. Once in a while SMD systems also grossly distort the vote-to-seat translation. The electorate may identify one party as the plurality party, but a different party may actually end up with a majority of the seats. A SMD electorate may move to the left and abandon a centre-left party for a more left-leaning small one. The effect will be to have the electorate moving left while the centre-right party derives the real benefit. It is more likely to become the majority party in parliament and hence to drive policy. PR systems on the

similar under the three measurement strategies and therefore are not an artifact of this aspect of our measurements.

${ }^{45}$ F. A. Hermans 'Democracy or Anarchy', The Review of Politics, (Notre Dame: University of Notre Dame, 1938). Reprinted in Harry Eckstein and David E. Apter, Comparative Politics: A Reader (New York: The Free Press, 1968); see especially pp. 273-74 in the reprinted version. On the persistence of this view, see Robert Richie and Steven Hill, eds. Reflecting All of Us: The Case for Proportional Representation (Boston: Beacon, 1999), especially John Ferejohn's essay, 'Cautionary Notes.'

${ }^{46}$ Douglas Rae, The Political Consequences of Electoral Laws, (New Haven: Yale University Press, 1967); Markku Laasko and Rein Taagepera, 'Effective Number of Parties: A Measure with Applications to Western Europe', Comparative Political Studies, 12 ( 1979), 3-27. Rein Taagepera and Matthew Shugart, Seats and Votes: The Effects and Determinants of Electoral Systems, (New Haven: Yale University Press, 1989); Arend Lijphart, Electoral Systems and Party Systems: A Study of Twenty-Seven Democracies, 1945-1990, (Oxford: Oxford University Press, 1994). 
other hand are more likely than SMD systems to line up median voters with parliamentary median and to put the party of the median parliamentarian in government in approximately 80 per cent of the cases. ${ }^{47}$

Finally, we can observe that the case for the median mandate is almost certainly stronger that we have presented it here. The analyses reported in Table 6 focus on government as the policy-making entity empowered by elections. As Kaare Strøm has observed, "government participation is not a necessary condition for policy payoff." 48 The power of the median may well be present on policy matters when the median position does not mark the position of the government. The party at the parliamentary median may share government ministries with parties to its left or right without ceding policy control. The median party may even allow a minority party to have all the ministries, as long as it can control that party's policy activity. The safeguard for representative democracy in terms of our thesis is that the parliamentary median retains the threat of government removal. Analyses of incongruence, representational bias, and responsiveness between the parliamentary median and the median voter (omitted here due to space considerations) show more congruence, less bias, and more direct and reliable responsiveness than what we have shown for governments and median voters.

\section{Applying a Median Mandate Approach to Elections}

Given the strong evidence for a median mandate actually functioning in contemporary democracies, what are the theoretical conclusions we can draw? Mainly, that we should stop thinking of elections as a clumsy and ineffective way of recording the majority choice of who should occupy government and reconceptualise them as recording the majority choice of policy. The precise mechanism through which this is done is by identifying the median voter preference and ensuring that this is also the policy position of the central (median) party in parliament.

\footnotetext{
${ }^{47}$ See n. 17.

${ }^{48}$ Kaare Strøm, Minority Government and Majority Rule, p. 38, emphasis in the original.
} 
It is important to note that the median mandate interpretation is a generalisation and updating of the traditional mandate, which has given the winning party its legitimacy in Western democracies. In traditional mandate theory a winning party gains office because a majority approves its programme, which it then must carry through in government. Unfortunately such an electoral majority is seldom seen in practice, contributing to the idea that elections are a broken mechanism so far as controlling government goes. In fact, mandate theory has often been pressed into service to justify 'elective dictatorships' based on pluralities that sometimes seem to be opposed by a popular majority.

What our reconceptualisation of elections does is to transfer the idea of the mandate from the governing party(ies) as such to the median party in parliament, provided its position corresponds closely to that of the median voter. A popular majority can be said to have endorsed that position and given a mandate to the party, which its centrality in legislative coalition building ensures it can carry out. If everything works out properly this is what should happen. The workings of elections and governments in twenty democracies over the post-war indicate that in broad terms it does happen, despite procedural imperfections.

A major finding is that PR is better at specifying and bringing together median voter and party positions than single member plurality districts. Under the idea that elections were about winning, PR has seemed an inefficient anomaly, particularly in the Anglo-American world, since it matches votes and seats in ways which rarely allow a clear majority winner to emerge. A consistent voice protesting this notion has been Arend Lijphart whose oft times heretical thesis has been that the resulting multi-party systems are better for negotiation and compromise - and ultimately popular satisfaction - than competitive two- or three-party systems. ${ }^{49}$

The weakness of 'consensus democracy', however, has been the absence of any clear and necessary connection between electors' preferences and elite responses. One can well believe that a benevolent elite in certain countries can arrive at optimal political solutions. But the process is

${ }^{49}$ Lijphart, The Politics of Accommodation; Democracies; Patterns of Democracy. 
hardly democratic when divorced from the actual results of elections. What we propose is precisely a reinterpretation that makes the electoral connection necessary, through the strategic role of the central party in representing the preferences of the median voter in elite negotiations. In so doing it contributes to synthesising 'two visions' of democracy that have often been taken as antithetical, ${ }^{50}$ and hopefully also to the rehabilitation of elections as a practical policy device in which every vote counts for defining the median.

On satisfaction with democracy, see Christopher J. Anderson and Christine A. Guillory, 'Political Institutions and Satisfaction with Democracy: A Cross-national Analysis of Consensus and Majoritarian Systems', American Political Science Review, 91 (1997), 66-81.

${ }^{50}$ Huber and Powell, 'Congruence between Citizens and Governments; Powell, Elections as Instruments of Democracy; Powell and Vanberg, 'Election Laws, Disproportionality and Median Correspondence; and Lijphart, himself, Democracies; Patterns of Democracy 


\section{Appendix}

Our measurement of a median voter's position relies on the procedure developed by HeeMin Kim and Richard Fording, with two adjustments discussed below. ${ }^{51}$ It differs from a survey-based measure in three respects. First, surveys asking respondents to locate themselves on a left-right scale often do not permit the identification of the party for whom a respondent had voted in an earlier national election. That requires the survey-based measure to refer to a median citizen rather than a median voter. ${ }^{52}$ Second, and more important, surveys that ask a left-right selfplacement question are infrequently available and hence are not applicable to time series analyses. Third, and most important, even if surveys did distinguish a median citizen from a median voter and even if they were more frequently available, they would not be up to the task of providing a good match to the party-position data. The party-position data are designed to have meaningful cross-national variation-i.e., if Norwegian parties locate themselves on average to the left of Australian parties of the same family (e.g., social democrats and conservatives), this can be taken as indicating that the Norwegian left-right space is left of the left-right space in Australia. This feature holds for the CMP data as well as for the 'expert' survey data. ${ }^{53}$ Mass survey data on respondents' left-right positions, on the contrary, appear to have no such cross-national variation.

In nearly all countries the median voter positions identified by mass surveys are quite similar. ${ }^{54}$ For example, the median citizen in Norway is recorded by surveys to be at the same leftright position as the median citizen in Australia, and even as the median citizen in the United States. ${ }^{55}$ This is implausible when one thinks of the general differences between these countries' politics, Norway by almost any account being well to the left of Australia or the United States. One consequence is that, but for three countries that stand three to four standard deviations to the left of all the others (viz., France, Italy, and Spain), the cross-national correlation between median

\footnotetext{
${ }^{51}$ Kim and Fording, 'Voter Ideology in Western Democracies, 1946-1989'; 'Extending Party Estimates to Governments and Electors'.

${ }^{52}$ Powell, Elections as Instruments of Democracies, pp 160-61. That can be more or less theoretically informative, depending on one's question. For our question, the median voter is the central concept.

${ }^{53}$ Peter Mair and Francis G. Castles, 'Revisting Expert Judgements', European Journal of Political Science, 31 (1997), 150-57.

${ }^{54}$ Powell, Elections as Instruments of Democracy, pp. 162, 180-85.
} 
citizen positions identified by surveys in the 1980s with those in the 1990s is almost nonexistent and, worse, negative-i.e., $r=-.14$. It appears, therefore, that voters in surveys report they are on the left, in the centre, or on the right within the context of their own country's political space, rendering their self-placements suspect for any comparative analysis and, more damning for present purposes, for matching to the party position data that do contain valid cross-national differences along the left-right dimension. The Kim-Fording measure uses leverage gained from the party system cross-national difference and has been validated in part by tests that pay attention to national political differences. ${ }^{56}$ And, we can note, the overtime $r=+.44$ for the Kim-Fording measure applied to same elections in the same 15 nations for which Powell's survey data correlation is -.14 .

The formula used by Kim and Fording is,

$$
\mathrm{M}=\mathrm{L}+[\{(50-\mathrm{C}) / \mathrm{F})\} * \mathrm{~W}] .
$$

Here:

$\mathrm{M}=$ median voter position, left-right.

$\mathrm{L}=$ lower end on the left-right dimension of the interval containing the median.

$\mathrm{C}=$ the cumulative vote percentage frequency up to but not including the interval containing the median.

$\mathrm{F}=$ the vote percentage of the party in the interval containing the median.

$\mathrm{W}=$ the width of the interval containing the median.

In a three party system, with parties at $\mathrm{P}, \mathrm{Q}$, and $\mathrm{R}$ at left-right positions of $-12,+2$, and +8 and vote percentages of 46,12 , and 41 , the median voter position is,

$$
\begin{aligned}
& \mathrm{M}=(-5)+[\{(50-47) / 12)\} * 10] \\
& M=-2.5
\end{aligned}
$$

The one adjustment we made to their measurement strategy involved situations when the farthest left or farthest right party in a system is involved in the formulation of either L or W. In those cases, Kim and Fording allow the extreme score of -100 or +100 to mark the endpoint where voters of that party are located. We find this implausible and its effect on the calculation

\footnotetext{
${ }_{55}^{55}$ Powell, Elections as Instruments of Democracies, pp 162.

${ }^{56}$ Kim and Fording, 'Voter Ideology in Western Democracies, 1946-1989'; 'Extending Party Estimates to Governments and Electors'.
} 
undesirable. In particular, the -100 and +100 endpoints can artificially stretch the distribution of voters around a party's position. Rather than assume the party's voters are so widely dispersed, we assume they are distributed in a symmetrical interval around the party's position. For example, for a leftmost party at -15 and a 0 midpoint between it and an adjacent party on the right, we assume the left boundary of that party's voters is -30 . With this marginal modification, the measure produces cross-national characterizations of considerable plausibility (see the national median voter positions in Table 5 above) as well as passing several reliability checks such as the correlations between the country placements over time, all of which add to the extensive series of checks reported by Kim and Fording themselves.

The great strength of the median measure, as with the Manifesto data themselves, is its ability to catch cross-national differences and over-time movements. This enables us to inspect structural, long-term features such as representativeness and responsiveness (Table 6), crucial to the assessment of whether mandates are operating. Static expert judgements and infrequent survey data on citizen self-placements have not allowed any of our predecessors to extend their investigations this far, thereby leading for example to harsh assessments of the extent to which majoritarian (SMD) systems coordinate popular preferences with public policy positions of parliaments and governments, which on our extended investigation are not altogether justified. 
Table 1: Conditions for a Government Mandate to Emerge

1. Party Distinctiveness - at least two parties have policy profiles distinct from one another

2. Voter information - voters recognize the policy profiles of each party.

3. Voter motivation - voters cast their ballots on the basis of the party policy profile they prefer to see implemented by a government.

4. Voter majority - a majority of voters are revealed to have the same preference, given the choices available.

5. Electoral system translation - the election outcome clearly designates the party with majority electoral support to form a government that will carry out its policy.

6. Party policy commitment - the party in government carries out its policies announced at the time of the election.

\section{Sources:}

These conditions are a synthesis of statements made by various authors about conditions required by mandate theory, referred to variously as conditions for the 'responsible party model', the 'Westminster model', and the popular control over public policy.

Nelson W. Polsby and Aaron B. Wildavsky Presidential Elections: Strategies of American Electoral Politics, $3^{\text {rd }}$ ed, (New York: Scribner, 1971), p. 225.

John L. Sullivan and Robert E. O'Connor 'Electoral Choice and Popular Control of Public Policy', American Political Science Review, 66 (1972), 1256-68, at pp. 1256-57.

Austin Ranney, Curing the Mischief of Faction: Party Reform in American, Berkeley and Los Angeles: University of California Press, 1975), p. 43.

Dennis Kavanagh, 'The Politics of Manifestos', Parliamentary Affairs, 34 (1981), 7-24.

John H. Aldrich Why Parties: The Origin and Transformation of Political Parties (Chicago: University of Chicago Press, 1995), pp. 10-12 
Table 2: Percentage of Time in Government and Number of Governments by Majority Status of Governments and Electorates in Five SMD Systems, Early 1950s through 1995

\begin{tabular}{|c|c|c|c|c|c|c|c|c|c|c|}
\hline \multirow{3}{*}{ Country } & \multicolumn{10}{|c|}{ Government and Electoral Status } \\
\hline & \multicolumn{2}{|c|}{$\begin{array}{c}\text { Govt Majority } \\
\& \\
\text { Elec Majority }\end{array}$} & \multicolumn{2}{|c|}{$\begin{array}{c}\text { Govt Majority } \\
\& \\
\text { Elec Plurality }\end{array}$} & \multicolumn{2}{|c|}{$\begin{array}{c}\text { Govt Majority } \\
\& \\
\text { Elec Minority }\end{array}$} & \multicolumn{2}{|c|}{$\begin{array}{c}\text { Govt Minority } \\
\& \\
\text { Elec Plurality }\end{array}$} & \multicolumn{2}{|c|}{$\begin{array}{c}\text { Govt Minority } \\
\& \\
\text { Elec Minority }\end{array}$} \\
\hline & $\%$ Time & \# Govt & $\%$ Time & \# Govt & $\%$ Time & \# Govt & $\%$ Time & \# Govt & $\%$ Time & \# Govt \\
\hline $\begin{array}{l}\text { Australia } \\
n=25\end{array}$ & 11.5 & 2 & 60.9 & 15 & 27.4 & 7 & 0.0 & 0 & 0.2 & 1 \\
\hline $\begin{array}{l}\text { Canada } \\
n=17\end{array}$ & 19.6 & 2 & 59.7 & 8 & 0.0 & 0 & 17.3 & 5 & 3.5 & 2 \\
\hline $\begin{array}{r}\text { France } \\
n=28\end{array}$ & 32.4 & 7 & 46.2 & 14 & 0.0 & 0 & 15.4 & 4 & 6.1 & 3 \\
\hline $\begin{array}{l}\text { New Zealand } \\
n=22\end{array}$ & 6.5 & 1 & 82.1 & 14 & 11.4 & 2 & 0.0 & 4 & 0.0 & 0 \\
\hline $\begin{array}{l}\text { United Kingdom } \\
\mathrm{n}=18\end{array}$ & 0.0 & 0 & 91.1 & 14 & 7.6 & 2 & 0.0 & 4 & 1.3 & 1 \\
\hline Totals $(\mathrm{N}=110)$ & & & & & & & & & & \\
\hline \# of Govt & & 12 & & 71 & & 11 & & 9 & & 7 \\
\hline \% of Govt & & $10.9 \%$ & & $64.5 \%$ & & $10.0 \%$ & & $8.2 \%$ & & $6.4 \%$ \\
\hline
\end{tabular}


Table 3: Percentage of Time in Government and Number of Governments by Majority Status of Governments and Electorates in 15 PR Systems, Early 1950s through 1995

\begin{tabular}{|c|c|c|c|c|c|c|c|c|}
\hline \multirow{3}{*}{ Country } & \multicolumn{8}{|c|}{ Government and Electoral Status } \\
\hline & \multicolumn{2}{|c|}{$\begin{array}{c}\text { Govt Majority } \\
\& \\
\text { Elec Majority }\end{array}$} & \multicolumn{2}{|c|}{$\begin{array}{c}\text { Govt Majority } \\
\& \\
\text { Elec Minority }\end{array}$} & \multicolumn{2}{|c|}{$\begin{array}{c}\text { Govt Minority } \\
\& \\
\text { Elec Minority }\end{array}$} & \multicolumn{2}{|c|}{$\begin{array}{l}\text { Caretaker } \\
\text { or } \\
\text { Nonpartisan }\end{array}$} \\
\hline & \%Time & \# Govt & $\%$ Time & \# Govt & $\%$ Time & \# Govt & $\%$ Time & \# Govt \\
\hline $\begin{array}{l}\text { Austria } \\
\mathrm{n}=18\end{array}$ & 87.2 & 16 & 9.3 & 1 & 3.5 & 1 & 0.0 & 0 \\
\hline $\begin{array}{l}\text { Belgium } \\
n=29\end{array}$ & 59.1 & 18 & 32.6 & 6 & 6.1 & 3 & 2.2 & 2 \\
\hline $\begin{array}{l}\text { Denmark } \\
\mathrm{n}=27\end{array}$ & 15.1 & 3 & 3.5 & 1 & 81.4 & 23 & 0.0 & 0 \\
\hline $\begin{array}{l}\text { Finland } \\
n=40\end{array}$ & 67.7 & 20 & 8.8 & 4 & 11.3 & 8 & 12.2 & 8 \\
\hline $\begin{array}{l}\text { Germany } \\
n=25\end{array}$ & 82.7 & 18 & 15.7 & 3 & 0.0 & 0 & 1.5 & 4 \\
\hline $\begin{array}{l}\text { Iceland } \\
n=18\end{array}$ & 91.1 & 14 & 0.0 & 0 & 8.9 & 4 & 0.0 & 0 \\
\hline $\begin{array}{l}\text { Ireland } \\
\mathrm{n}=19\end{array}$ & 12.8 & 3 & 42.6 & 6 & 44.6 & 10 & 0.0 & 0 \\
\hline $\begin{array}{l}\text { Italy } \\
n=46\end{array}$ & 49.7 & 21 & 10.7 & 4 & 35.4 & 17 & 4.2 & 4 \\
\hline $\begin{array}{l}\text { Luxembourg } \\
\mathrm{n}=14\end{array}$ & 89.6 & 13 & 10.4 & 1 & 0.0 & 0 & 0.0 & 0 \\
\hline $\begin{array}{l}\text { Netherlands } \\
\mathrm{n}=18\end{array}$ & 87.7 & 13 & 8.1 & 1 & 0.0 & 0 & 4.2 & 4 \\
\hline $\begin{array}{l}\text { Norway } \\
n=21\end{array}$ & 0.0 & 0 & 36.0 & 6 & 64.0 & 15 & 0.0 & 0 \\
\hline $\begin{array}{l}\text { Portugal } \\
n=13\end{array}$ & 48.1 & 4 & 14.8 & 3 & 31.3 & 3 & 5.8 & 3 \\
\hline $\begin{array}{l}\text { Spain } \\
n=7\end{array}$ & 19.4 & 1 & 17.9 & 1 & 62.8 & 5 & 0.0 & 0 \\
\hline $\begin{array}{l}\text { Sweden } \\
n=21\end{array}$ & 21.0 & 5 & 3.7 & 1 & 75.3 & 15 & 0.0 & 0 \\
\hline $\begin{array}{l}\text { Switzerland } \\
n=45\end{array}$ & 100.0 & 45 & 0.0 & 0 & 0.0 & 0 & 0.0 & 0 \\
\hline Totals $(\mathrm{N}=361)$ & & & & & & & & \\
\hline \# of Govt & & 194 & & 38 & & 104 & & 25 \\
\hline \% of Govt & & $53.7 \%$ & & $10.5 \%$ & & $28.8 \%$ & & $6.9 \%$ \\
\hline
\end{tabular}


Table 4: Conditions for a Median Mandate to Emerge

1. Party distinctiveness - at least two parties have policy positions that differ from one another.

2. Vote information - voters recognize the policy profiles of the parties.

3. Voter motivation - voters cast their ballots on the basis of the party policy position they prefer to in control policy making.

4. Shared party-voter alignment - voters and parties arrange their public policy preferences within broadly the same policy space, probably a left-right dimension.

5. Electoral system translation - the election outcome makes the party supported by the median voter the party with which the median parliamentarian affiliates.

6. Party policy commitment - parties are motivated by a desire to see their own policy position control policy making.

7. Power of the median - the occupant o the median position is crucial to the creation of a majority in both the electorate and parliament.

(a) Majority-endorsed preferences tend towards the median voter position, so this forms the best indicator of popular policy preferences in general.

(b) Public policy tends towards the policy of the parliamentary median under legislative majority voting procedures. 
Table 5: Data Coverage and Summaries of Median Voter, Parliament, and Government Left-Right Positions, by Country from the early 1950s through 1995

\begin{tabular}{|c|c|c|c|c|c|c|c|c|c|c|}
\hline \multirow[t]{2}{*}{ Country } & \multicolumn{4}{|c|}{ Governments \& Elections } & \multicolumn{6}{|c|}{$\begin{array}{c}\text { Across-time } \\
\text { Left-Right Position a }\end{array}$} \\
\hline & $\begin{array}{l}\text { \# of } \\
\text { Govts }\end{array}$ & $\begin{array}{c}\text { Sequence } \\
\text { Covered } \\
\text { W-K-B }\end{array}$ & $\begin{array}{c}\text { Nonpartisan } \\
\text { or } \\
\text { Caretaker }\end{array}$ & $\begin{array}{c}\text { \# of } \\
\text { Elections }\end{array}$ & $\begin{array}{r}\mathbf{M e} \\
\mathbf{V} \\
\text { Mean }\end{array}$ & $\begin{array}{l}\text { dian } \\
\text { oter } \\
\text { Std Dev }\end{array}$ & $\begin{array}{r}\text { Parliar } \\
\mathbf{M} \\
\text { Mean }\end{array}$ & $\begin{array}{l}\text { mentary } \\
\text { edian } \\
\text { Std Dev }\end{array}$ & $\begin{array}{c}\text { Wei } \\
\text { Gov } \\
\text { Mean }\end{array}$ & $\begin{array}{l}\text { ghted } \\
\text { it Mean } \\
\text { Std Dev }\end{array}$ \\
\hline Australia & 25 & $4-28$ & & 18 & 5.5 & 10.7 & 9.3 & 22.6 & 9.0 & 20.3 \\
\hline Austria & 18 & $3-20$ & & 13 & -4.2 & 14.8 & -3.2 & 15.6 & -4.2 & 15.9 \\
\hline Belgium & 29 & $9-37$ & 26,34 & 15 & -4.2 & 8.2 & -3.1 & 7.6 & -4.7 & 9.0 \\
\hline Canada & 17 & $4-20$ & & 14 & -2.8 & 6.1 & -1.6 & 8.9 & 0.3 & 10.6 \\
\hline Denmark & 27 & $3-29$ & & 19 & -4.7 & 9.6 & -6.9 & 9.8 & -3.7 & 21.8 \\
\hline Finland & 40 & $7-46$ & $\begin{array}{c}9,16,17,23 \\
27,30,32,33\end{array}$ & 13 & -12.7 & 14.1 & -12.3 & 13.8 & -9.2 & 21.0 \\
\hline France & 28 & $29-56$ & & 10 & -4.9 & 7.6 & 4.9 & 16.5 & 3.9 & 18.5 \\
\hline Germany & 25 & $2-26$ & $8,12,20,21$ & 12 & 0.9 & 11.0 & 1.7 & 16.1 & 3.6 & 19.7 \\
\hline Iceland & 18 & $5-22$ & & 13 & -5.4 & 11.4 & -3.9 & 13.0 & -3.1 & 15.2 \\
\hline Ireland & 19 & $2-20$ & & 14 & 3.8 & 15.3 & 2.4 & 19.7 & 4.2 & 16.1 \\
\hline Italy & 46 & $8-53$ & $9,19,34,37$ & 10 & -5.1 & 7.6 & -3.7 & 7.2 & -5.5 & 7.8 \\
\hline Luxembourg & 14 & $4-17$ & & 10 & -15.1 & 9.0 & -12.1 & 8.7 & -14.7 & 11.8 \\
\hline Netherlands & 18 & $4-21$ & $6,10,13,17$ & 13 & -7.7 & 12.9 & -6.0 & 12.7 & -6.8 & 12.1 \\
\hline New Zealand & 22 & $3-24$ & & 15 & -8.6 & 8.2 & -4.3 & 16.0 & -7.4 & 14.7 \\
\hline Norway & 21 & $4-24$ & & 11 & -24.3 & 7.1 & -25.7 & 8.1 & -22.0 & 13.5 \\
\hline Portugal & 13 & $1-13$ & $3,4,5$ & 8 & -6.8 & 8.0 & -5.0 & 9.9 & -3.4 & 9.7 \\
\hline Spain & 7 & $1-7$ & & 6 & -11.7 & 8.0 & -11.4 & 10.2 & -9.7 & 10.3 \\
\hline Sweden & 21 & $4-24$ & & 15 & -16.6 & 16.6 & -19.5 & 17.0 & -20.9 & 21.5 \\
\hline Switzerland & 45 & $8-52$ & & 12 & 4.7 & 8.2 & 4.5 & 9.7 & 5.0 & 9.8 \\
\hline United Kingdom & 18 & $2-19$ & & 13 & -10.4 & 12.2 & -4.1 & 24.8 & -7.2 & 26.1 \\
\hline TOTALS & 471 & & & 254 & & & & & & \\
\hline
\end{tabular}

${ }^{a}$ Cell entries under Median Voter and Parliamentary Median use the number of elections as the basis of the calculations in order not to double, treble, $\ldots$ an average median position across time merely because two, three, ... governments formed after the election. Cell entries under Weighted Govt Mean use the number of governments as the basis of the calculation, not including caretaker or nonpartisan governments. Left positions are negative, center equals zero; and right positions are positive. 
Table 6: Congruence, Long-term Represntativeness, and Responsiveness between Left-Right Position of Governments, Weighted by Party Size, and Left-Right Position of Median Voter, 20 Western Democracies 1950s through 1995

\begin{tabular}{|c|c|c|c|c|c|c|c|c|}
\hline \multicolumn{2}{|c|}{ System } & \multirow{2}{*}{\begin{tabular}{|c|} 
Incongruence $^{\mathrm{a}}$ \\
$\begin{array}{c}\text { Mean } \\
\text { (std dev) }\end{array}$
\end{tabular}} & \multirow{2}{*}{\begin{tabular}{|c|}
$\begin{array}{c}\text { Long-term } \\
\text { Representativenesss }\end{array}$ \\
$\begin{array}{c}\text { Mean } \\
\text { (std dev) }\end{array}$
\end{tabular}} & \multicolumn{4}{|c|}{ Responsiveness $^{c}$} & \multirow[b]{2}{*}{$\mathbf{N}$} \\
\hline & Country & & & $\begin{array}{c}\text { Intercept } \\
\left(s_{\mathrm{a}}\right)\end{array}$ & $\begin{array}{c}\text { Slope } \\
\left(s_{b}\right)\end{array}$ & $R^{2}$ & $s_{e}$ & \\
\hline \multirow[t]{5}{*}{ SMD } & Australia & $\begin{array}{l}18.2 \\
(9.1)\end{array}$ & $\begin{array}{r}7.1 \\
(19.4)\end{array}$ & $\begin{array}{r}7.8 \\
(3.9)\end{array}$ & $\begin{array}{l}.64^{*} \\
(.35)\end{array}$ & .12 & 19.4 & 25 \\
\hline & Canada & $\begin{array}{r}6.1 \\
(7.8)\end{array}$ & $\begin{array}{r}3.6 \\
(9.3)\end{array}$ & $\begin{array}{r}3.1 \\
(2.7)\end{array}$ & $\begin{array}{l}.85^{\star} \\
(.39)\end{array}$ & .23 & 9.6 & 17 \\
\hline & France & $\begin{array}{l}18.9 \\
(8.3)\end{array}$ & $\begin{array}{c}9.9 \\
(18.4)\end{array}$ & $\begin{array}{r}7.0 \\
(4.4)\end{array}$ & $\begin{array}{l}.53 \\
(.45)\end{array}$ & .05 & 18.4 & 28 \\
\hline & New Zealand & $\begin{array}{l}12.4 \\
(7.0)\end{array}$ & $\begin{array}{c}1.2 \\
(14.4)\end{array}$ & $\begin{array}{l}-2.6 \\
(4.7)\end{array}$ & $\begin{array}{l}.56 \\
(.40)\end{array}$ & .08 & 14.4 & 22 \\
\hline & United Kingdom & $\begin{array}{c}14.6 \\
(11.1)\end{array}$ & $\begin{array}{c}4.1 \\
(18.2)\end{array}$ & $\begin{array}{l}10.3 \\
(5.5)\end{array}$ & $\begin{array}{l}1.55^{* *} \\
(.32)\end{array}$ & .59 & 17.3 & 18 \\
\hline \multicolumn{2}{|c|}{ SMD Summary } & $\begin{array}{l}14.8 \\
(9.6)\end{array}$ & $\begin{array}{c}5.6 \\
(16.8)\end{array}$ & & & & & 110 \\
\hline \multirow[t]{15}{*}{$P R$} & Austria & $\begin{array}{r}6.6 \\
(4.4)\end{array}$ & $\begin{array}{l}-1.6 \\
(8.0)\end{array}$ & $\begin{array}{l}-1.5 \\
(2.0)\end{array}$ & $\begin{array}{l}1.02^{* *} \\
(.15)\end{array}$ & .75 & 8.2 & 18 \\
\hline & Belgium & $\begin{array}{r}5.5 \\
(4.8)\end{array}$ & $\begin{array}{r}0.0 \\
(7.4)\end{array}$ & $\begin{array}{c}-.9 \\
(1.5)\end{array}$ & $\begin{array}{l}.81^{* *} \\
(.17)\end{array}$ & .46 & 7.2 & 27 \\
\hline & Denmark & $\begin{array}{c}16.1 \\
(11.6)\end{array}$ & $\begin{array}{r}1.4 \\
(20.0)\end{array}$ & $\begin{array}{c}1.1 \\
(4.5)\end{array}$ & $\begin{array}{l}.94^{*} \\
(.44)\end{array}$ & .15 & 20.4 & 27 \\
\hline & Finland & $\begin{array}{c}13.6 \\
(14.9)\end{array}$ & $\begin{array}{r}6.6 \\
(19.1)\end{array}$ & $\begin{array}{l}3.8 \\
(5.1)\end{array}$ & $\begin{array}{l}.80^{* *} \\
(.25)\end{array}$ & .23 & 18.8 & 32 \\
\hline & Germany & $\begin{array}{r}9.4 \\
(9.0)\end{array}$ & $\begin{array}{r}2.3 \\
(13.0)\end{array}$ & $\begin{array}{c}1.7 \\
(2.5)\end{array}$ & $\begin{array}{l}1.45^{* *} \\
(.26)\end{array}$ & .58 & 12.5 & 21 \\
\hline & Iceland & $\begin{array}{r}7.5 \\
(8.4)\end{array}$ & $\begin{array}{r}4.2 \\
(10.5)\end{array}$ & $\begin{array}{c}4.5 \\
(3.2)\end{array}$ & $\begin{array}{l}1.04^{* *} \\
(.25)\end{array}$ & .52 & 10.6 & 18 \\
\hline & Ireland & $\begin{array}{r}8.5 \\
(8.8)\end{array}$ & $\begin{array}{r}0.6 \\
(12.3)\end{array}$ & $\begin{array}{c}1.7 \\
(2.7)\end{array}$ & $\begin{array}{l}.70^{* *} \\
(.17)\end{array}$ & .51 & 11.7 & 19 \\
\hline & Italy & $\begin{array}{c}1.8 \\
(1.8)\end{array}$ & $\begin{array}{r}0.9 \\
(2.4)\end{array}$ & $\begin{array}{l}1.4^{* *} \\
(.5)\end{array}$ & $\begin{array}{l}1.07^{\star \star} \\
(.06)\end{array}$ & .87 & 2.8 & 42 \\
\hline & Luxembourg & $\begin{array}{r}4.3 \\
(3.4)\end{array}$ & $\begin{array}{l}-0.1 \\
(5.6)\end{array}$ & $\begin{array}{r}2.4 \\
(3.0)\end{array}$ & $\begin{array}{l}1.17^{* *} \\
(.17)\end{array}$ & .79 & 5.7 & 14 \\
\hline & Netherlands & $\begin{array}{r}7.3 \\
(4.0)\end{array}$ & $\begin{array}{c}1.4 \\
(8.5)\end{array}$ & $\begin{array}{l}-.1 \\
(2.1)\end{array}$ & $\begin{array}{l}.79^{* *} \\
(.14)\end{array}$ & .67 & 7.3 & 14 \\
\hline & Norway & $\begin{array}{l}10.3 \\
(7.0)\end{array}$ & $\begin{array}{r}2.7 \\
(12.4)\end{array}$ & $\begin{array}{c}-.7 \\
(11.4)\end{array}$ & $\begin{array}{l}.86^{*} \\
(.45)\end{array}$ & .16 & 12.7 & 21 \\
\hline & Portugal & $\begin{array}{r}4.7 \\
(2.8)\end{array}$ & $\begin{array}{r}2.9 \\
(4.7)\end{array}$ & $\begin{array}{c}3.7 \\
(2.1)\end{array}$ & $\begin{array}{l}1.12^{* *} \\
(.22)\end{array}$ & .77 & 4.9 & 10 \\
\hline & Spain & $\begin{array}{r}3.6 \\
(2.3)\end{array}$ & $\begin{array}{r}1.1 \\
(4.3)\end{array}$ & $\begin{array}{r}3.7 \\
(2.9)\end{array}$ & $\begin{array}{l}1.24^{* *} \\
(.23)\end{array}$ & .86 & 4.3 & 7 \\
\hline & Sweden & $\begin{array}{r}8.8 \\
(7.7)\end{array}$ & $\begin{array}{c}-3.1 \\
(11.4)\end{array}$ & $\begin{array}{c}1.5 \\
(3.8)\end{array}$ & $\begin{array}{l}1.25^{* *} \\
(.17)\end{array}$ & .75 & 11.0 & 21 \\
\hline & Switzerland & $\begin{array}{r}4.5 \\
(3.2)\end{array}$ & $\begin{array}{c}0.6 \\
(5.5)\end{array}$ & $\begin{array}{c}.6 \\
(1.0)\end{array}$ & $\begin{array}{l}1.00^{* *} \\
(.10)\end{array}$ & .68 & 5.6 & 45 \\
\hline \multicolumn{2}{|c|}{ PR Summary } & $\begin{array}{r}7.6 \\
(8.5)\end{array}$ & $\begin{array}{c}1.4 \\
(11.3)\end{array}$ & & & & & 336 \\
\hline
\end{tabular}

$* \mathrm{p}<.05 ; * * \mathrm{p}<.01$; two-tail critical values for intercepts and one-tail critical values for slopes.

${ }^{\mathrm{a}}$ Incongruence is the absolute value of the difference between the weighted mean left-right position of the governments (with weights proportional to the number of seats held by each party in government) and the left right position of the median voter. $\mathrm{N}=$ the number of governments; caretaker and nonpartisan governments are excluded. Totally congruent systems would have a mean equal to zero.

${ }^{\mathrm{b}}$ Long-term representativeness is the average difference between the weighted mean left-right position of the government (with weights as above) and the left right position of the median voter. $\mathrm{N}=$ the number of governments; caretaker and nonpartisan governments are excluded. A mean equal to zero indicates accurate (i.e., unbiased) long-term representativeness. 
${ }^{c}$ Responsiveness is evaluated by the linear relationship between the weighted mean left-right position of the government (Y) and the left-right position of the median voter $(\mathrm{X})$. Left positions are negative, center equals zero; and right positions are positive. 
Figure 1: The Dominant Position of the Median Actor, $C$, in a One-dimensional Policy Space

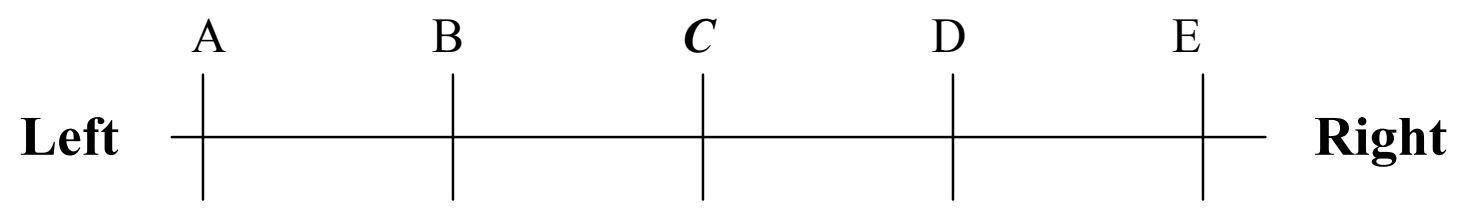


Figure 2: Relationships between Parliamentary Median and Median Voter Left-Right Positions, by Electoral System Type

\section{PR Systems}

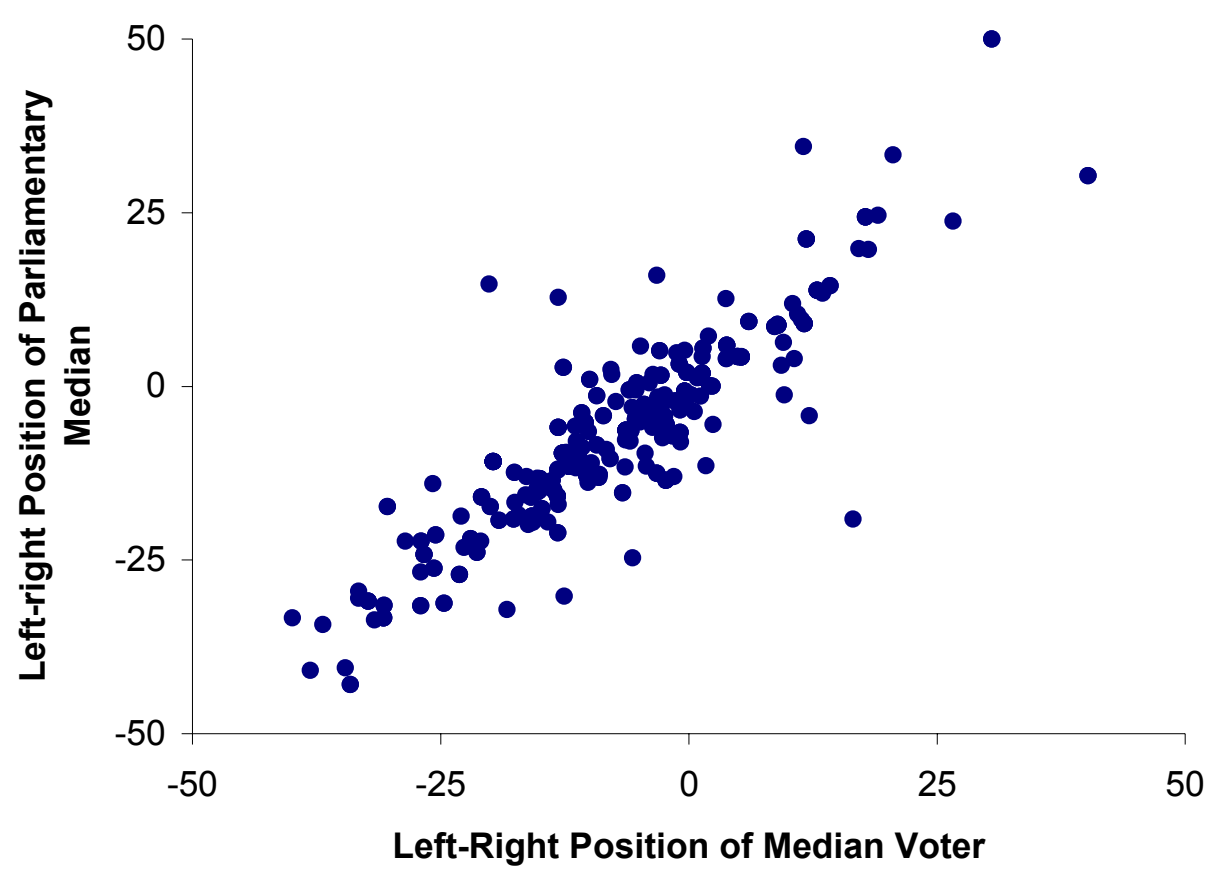

\section{SMD Systems}

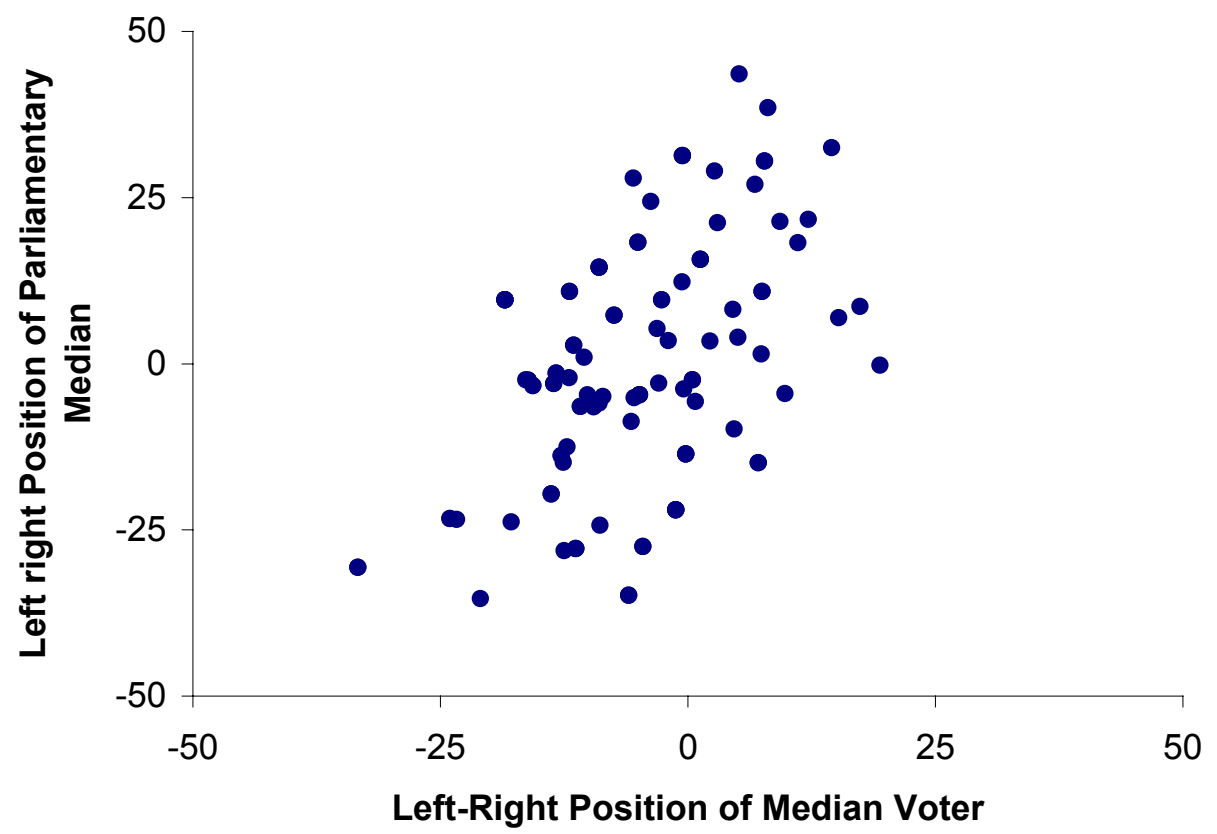

